\title{
Continuous Improvement in Mixer Grinder Assembly Line through Lean Tools
}

\author{
Senthilkumar $\mathbf{M}^{1}$, Anusree AM, Gopal G K and Shivram R \\ \{msk.prod@psgtech.ac.in ${ }^{1}$, anusreeathi96@gmail.com².gopikrisu.gk@gmail.com³ \\ shivramblaji96@gmail.com ${ }^{4}$ \} \\ Department of Production Engineering, PSG College of Technology, Coimbatore, India
}

\begin{abstract}
Companies have to improve their productivity to compete in the ever growing manufacturing company. This study describes the improvement activities of the ELGI ultra company in India using lean tools and line balancing techniques. The objective is to improvise the productivity of mixer grinder assembly by reducing time and worker motion. The time study and line techniques were used in the assembly line. A bottleneck station was recognized to where the operation is inadequate in assembly line layout and workplace organization. The novel workplace layout and better working method for operators were designed and executed. The time after improvement is estimated and the future state of the process has been mapped and the future state map is created. As a result the idle time in each station has been reduced and total work content time in the assembly process has been reduced by eliminating some non-value adding activities.
\end{abstract}

Keywords: Assembly line, Lean manufacturing tools, Line balancing, Productivity, Value stream mapping.

\section{Introduction}

The work reported here has been carried out in ELGI Ultra Industries, Coimbatore, a leading manufacturer of grinders, pressure cookers and mixer grinders. This industry offers advanced and dependable products. Mixer grinders, pressure cookers and grinders are widely used products in the domestic store. The manufacturing and assembly of these products has evolved to significant extent over the years as several research focuses is given to the design aspects of these products. For a product to be successful, both the design and production activities should be perfect. This paper focuses on the improvement of assembly process of the mixer grinder using value stream mapping approach. The product chosen for the study is Stealth type mixer grinder. The main aim of this paper is to study the assembly of the mixer grinder and to identify and reduce the non-value added activities taking place in the various work stations thereby increasing the productivity.

The main objectives of this work are, to eliminate the non-value adding activities, to reduce the waiting time in the work stations, to identify and eliminate the muda (waste) in the assembly line, to establish single piece flow in the process by reducing work in progress, to streamline the production of the mixer grinders and to increase the line balance efficiency of the assembly line by using line balancing techniques. 


\section{Methods}

\subsection{The methodology followed in this work}

The methodology is presented as follows:

$\begin{array}{ll}\text { 1. } & \text { Problem definition } \\ \text { 2. } & \text { Literature survey } \\ \text { 3. } & \text { Product selection } \\ \text { 4. } & \text { Conduct of time study } \\ \text { 5. } & \text { Critical path analysis } \\ \text { 6. } & \text { Current state value stream map } \\ \text { 7. } & \text { Analysis of current state } \\ \text { 8. } & \text { Improvement ideas } \\ \text { 9. } & \text { Future state value stream map } \\ \text { 10. } & \text { Implementation } \\ \text { 11. } & \text { Productivity assessment }\end{array}$

\section{Experimental}

\subsection{Time Study}

Time study for drive unit assembly line and jar assembly line are taken using stop watch method. From the observed value, using Westinghouse system and considering worker allowance factors from the standards the standard time is calculated for the drive unit assembly line.

\begin{tabular}{|c|c|c|}
\hline 氙 & Tasks & $\underset{\underbrace{}}{\stackrel{\Xi}{\Xi}}$ \\
\hline 10 & $1,2,3,4,5,6,7,8.9$ & 107 \\
\hline 20 & $10,11,12,13,14,15,16,17,18$ & 140 \\
\hline 30 & $19,20,21,22,23,24,25$ & 153 \\
\hline 40 & $26,27,28.29 .30,31$ & 126 \\
\hline 50 & $\begin{array}{c}32,33,34,35,36,37,38,39,40,41 \\
42,43,44,45\end{array}$ & 126 \\
\hline 60 & $46,47,48,49,50,51,52,53,54$ & 75 \\
\hline 70 & $55,56,57$ & 65 \\
\hline
\end{tabular}




\begin{tabular}{|c|c|c|}
\hline 80 & $58,59,60,61,62,63,64$ & 217 \\
\hline \multirow{3}{*}{} & Total work comment time & 1009 \\
\hline
\end{tabular}

Table 1 Tasks and Time Taken at Each Station in the Drive Unit Assembly Line

\begin{tabular}{|c|c|c|}
\hline $\begin{array}{c}\text { Station } \\
\text { no. }\end{array}$ & Tasks & $\begin{array}{c}\text { Time } \\
\text { (s) }\end{array}$ \\
\hline J10 & $1,2,3$ & 18 \\
\hline J20 & $4,5,6,7$ & 94 \\
\hline J30A & $8,9.10,11,1213,14,15$ & 152 \\
\hline J30B & $16,17,18,19,20$ & 103 \\
\hline J70 & $21,22,23$ & 134 \\
\hline J80 & $24,25,26,27,28,29,30$ & 217 \\
\hline \multicolumn{2}{|c|}{ Total work content time } & 718 \\
\hline
\end{tabular}

Table 2 Tasks and Time Taken at Each Station in the Jar Assembly Line

\subsection{Critcal path Analysis}

Critical path method is the technique used for the analysis of the assembly line in the mixer grinder model stealth. Since there are more parallel paths involved, there is need for the study of the individual paths involved and plot the value stream mapping. There are four parallel paths involved in the total assembly of a mixer grinder including jar assembly, mixer and packaging. The four parallel paths are as follows,

Path 1 : ( Drive unit assembly )

Path 2 : ( SQJ L Jar assembly )

Path $3:$ ( 0.8 L Jar assembly )

Path 4 : ( 1.5 L Jar assembly ) 


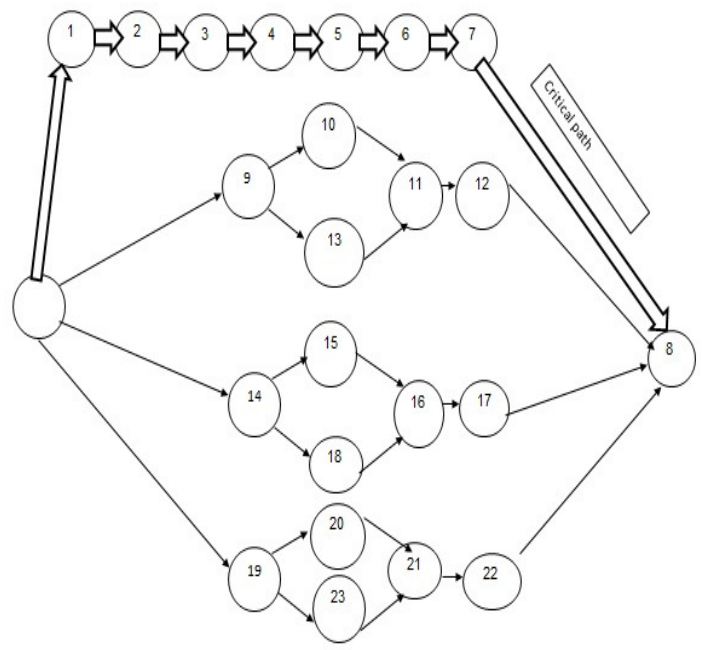

Fig. 1. Network diagram

\subsection{Takt time calculation}

Takt time gives the pace at which the product should be produced. Takt time is given by the ratio of available time and total demand. The line operates for an 8.5 hours shift with a break of 60 minutes. The demand per shift per line is 220 units.

\begin{tabular}{|c|c|c|c|c|}
\hline & $\begin{array}{c}\text { Mixer } \\
\text { drive unit } \\
\text { assembly }\end{array}$ & $\begin{array}{c}\text { SQJ } \\
\text { Jar }\end{array}$ & $\begin{array}{c}\mathbf{0 . 8} \text { L } \\
\text { Jar }\end{array}$ & $\begin{array}{c}\mathbf{1 . 5} \text { L } \\
\text { Jar }\end{array}$ \\
\hline $\begin{array}{c}\text { Total } \\
\text { working } \\
\text { time ( s ) }\end{array}$ & $\S$ & $\S$ & $\S$ & $\S$ \\
\hline $\begin{array}{c}\text { Takt } \\
\text { time( s ) }\end{array}$ & 122 & 122 & 122 & 122 \\
\hline \multicolumn{3}{|c}{ Table 3 Takt Time Calculations } \\
\hline
\end{tabular}

\subsection{Process ratio calculation}

The value added time is the addition of processing time of all processes. Process ratio is calculated using the equation (1).

Process ratio $=\mathrm{V} /(\mathrm{V}+\mathrm{D})$

where, $\mathrm{V}$ is the value adding time and $\mathrm{D}$ is the delay time. 


\begin{tabular}{|c|c|c|}
\hline & Drive unit assembly & Jar assembly \\
\hline V (s) & 557 & 410 \\
\hline D (s) & 305 & 208 \\
\hline Process ratio (\%) & 63.8 & 66.3 \\
\hline
\end{tabular}

Table 4 Process Ratio Calculations

\subsection{Improvement Ideas}

In station 10, due to lack of fixture difficulty in assembling the rotary switch assembly onto the top cover, so fixture is designed. In station 10 and 20, no provision to dispose of the plastic covers, searching for tools and mixing up of parts from stealth, vario and duramix models which implies there is lack of $5 \mathrm{~S}$ and poor workplace design, in order to eliminate these $5 \mathrm{~S}$ implementation is required by colour coding of component trays, introduction of tool shadow boards and introduction of waste bins for disposal. In station 30, more time for fastening bolt, spring washer and washer, so redesign of the part is required. In station 50, operator has to walk a lot in order to fetch the base component because there is no rack provided to hold the drive unit base component, which can be improved by placing a table near the workstation to accommodate the base units for faster assembly. In station 80, operator has to bend more to pack the mixer grinder due to poor workplace design which can be improved by ergonomically inclined table to enable easy packing.

The improvement ideas for drive unit assembly line are implemented and $\mathrm{S}$ hence the total cycle time for drive unit line becomes lesser than the jar assembly. To eliminate the nonvalue adding activities and to match the cycle time of the jar assembly stations with the takt time, the current state map was plotted for the jar assembly line. There are three jar assembly operations namely the SQJ, 0.8L and 1.5L happening simultaneously. Each jar assembly line consists of 4 stations involving 4 operators. The wastes identified in the jar unit assembly stations. Two kinds of waste namely, motion and waiting have been identified. Lean tools such as $5 \mathrm{~S}$ and poka-yoke have been proposed to reduce the occurrence of these wastes and thereby increasing the productivity, on-time delivery and boosting the morale of the workers.

\section{Results}

A bar chart for the stations 10 to 80 is plotted using the time taken before the implementation of the improvement ideas and time taken after the implementation of improvements shows that before the implementation of improvement ideas there was imbalance in the line and after implementation and line balancing the cycle time of each station equals to the takt time. 

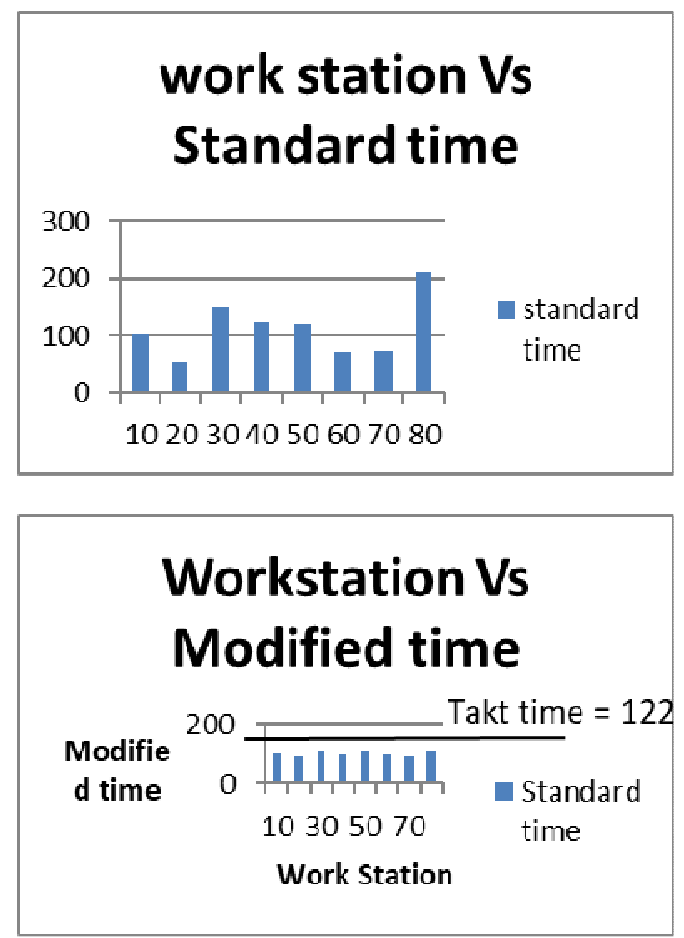

Fig. 2. Bar chart depiction of stations before and after improvements

\section{Discussion}

The line balancing efficiency for the assembly line has been calculated using the equation (4.1).. Twc denotes the total work content time in the assembly process, w denotes the no of workstations and $\mathrm{Tb}$ denotes the bottleneck time.

$$
\begin{aligned}
& \text { Line balance efficiency }=\mathrm{T}_{\mathrm{wc}} /\left(\mathrm{w} * \mathrm{~T}_{\mathrm{b}}\right) \\
&= 903 /(8 * 212) \\
&= 53.24 \%
\end{aligned}
$$

After the implementation of the improvements the line balance efficiency is,

Line balance efficiency $=\mathrm{T}_{\mathrm{wc}} /\left(\mathrm{w} * \mathrm{~T}_{\mathrm{b}}\right)$

$$
\begin{gathered}
=805 /(8 * 110) \\
=91.47 \%
\end{gathered}
$$




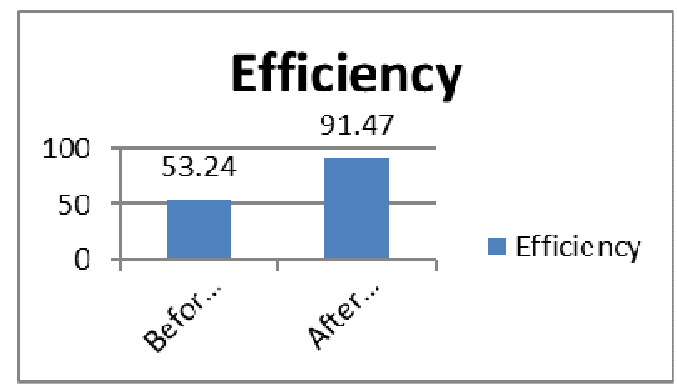

Fig 3 Line balance efficiency

\section{Conclusion}

The objective of paper is to improve the productivity of the stealth model mixer grinder assembly line. Earlier the line balance efficiency was $53.24 \%$ and after the implementation of the improvement ideas the line balance efficiency is $91.47 \%$. This study not only focuses on the productivity improvement but also facilities the ease of assembly processes to the worker by ergonomic considerations and improvements. The improved line has a production capacity of 220 mixer grinders per shift.

\section{References}

[1]. AR Rahani, Muhammad al-Ashraf, "Production flow analysis through value stream mapping: a lean manufacturing process case study", Procedia Engineering, vol. 41, pp. 1727-1734, 2012.

[2]. D Rajenthirakumar, R Sridhar, "Development of lean assembly line", International Journal of Lean Thinking, vol. 5, December 2014.

[3]. J Oliveira, J C Sa, A Fernandes, "Continuous improvement through lean tools: An application in a mechanical company", Procedia Manufacturing vol.13, pp. 1082-1089, 2017.

[4]. K Venkataraman, B Ramnath., V Muthu Kumar, C Elanchezhian, "Application of value stream mapping for reduction of cycle time in a machining process", Procedia Materials Science, vol. 6, pp. 1187-1196, 2014.

[5]. Meghali Gaikwad, Dhanashri Shevade, Bhat Prasad Krishna, "Value stream mapping: a case study of an assembly line in an automotive industry", International Journal of Current Engineering and technology, vol.4, March 2016.

[6]. Minh-Nhat Nguyen, Ngoc-Hien Do, "Re-engineering assembly line with lean techniques", Procedia CIRP, vol. 40, pp. 590-595, 2016.

[7]. R sundar, A N Balaji R M Satheeshkumar, "A review on lean manufacturing implantation techniques”, Procedia Engineering, vol.97, pp.1875-1885, 2014.

[8]. Sherif Mostafa, Jantanee Dumrak, "Waste elimination for manufacturing sustainability", Procedia Manufacturing, pp. 11-16, 2015.

[9]. S Santhosh Kumar, M Pradeep Kumar, "Cycle time reduction of a truck body assembly in an automobile industry by lean principles”, Procedia Materials Science, vol. 5, pp. 1853-1862, 2014.

[10]. Tomas Rohac, Martin Januska, "Value stream mapping demonstration on real case study", Procedia Engineering, vol. 100, pp. 520-529, 2014 